\title{
EVALUASI PELATIHAN TEKNIS PELAYANAN PUBLIK BALAI DIKLAT KEAGAMAAN JAKARTA DENGAN MODEL CIPP
}

\author{
Rahmat Aulia \\ Balai Diklat Keagamaan Jakarta, Indonesia \\ E-mail: aulaulia372@gmail.com
}

\begin{abstract}
This study aims to evaluate learning programs in public service training in work area at BDK Jakarta using the CIPP model of evaluation. Researcher's focus is 1) context evaluation: program suitability with learning needs and objectives, 2) input evaluation: learning citizens, tutors, funding, facilities and infrastructure, 3) process evaluation: learning activities, tutor activities, methods, learning materials and learning citizen participation, 4) product evaluation: achievement of goals and evaluation process. This research is an evaluative descriptive study with a qualitative approach. Data collection techniques used are observation, interviews, and documentation. The validity of the data uses triangulation techniques. The results showed that overall, the public service training at BDK Jakarta was good and in accordance with the stated objectives. Otherwise, researcher found that product evaluation was only done at the end of the course.
\end{abstract}

Keywords: public service training, learning evaluation, CIPP

\begin{abstract}
Abstrak
Penelitian ini bertujuan mengevaluasi program pembelajaran pada pelatihan teknis pelayanan publik di BDK Jakarta dengan menggunakan model evaluasi CIPP. Fokus peneliti adalah: 1) evaluasi konteks: kesesuaian program dengan kebutuhan dan tujuan pembelajaran, 2) evaluasi masukan: warga belajar, tutor, pendanaan, sarana dan prasarana, 3) evaluasi proses: aktifitas warga belajar, aktifitas tutor, metode, materi pembelajaran dan partisipasi warga belajar, 4) evaluasi produk: ketercapaian tujuan dan proses evaluasi. Penelitian ini merupakan penelitian deskriptif evaluatif dengan pendekatan kualitatif. Teknik pengumpulan data yang digunakan adalah observasi, wawancara dan dokumentasi. Keabsahan data menggunakan teknik triangulasi. Hasil penelitian menunjukkan bahwa secara keseluruhan pembelajaran pada pelatihan teknis pelayanan publik di wilayah kerja BDK Jakarta sudah bagus dan sesuai dengan tujuan yang ditetapkan. Ditemukan kekurangan pada pelatihan ini hanya pada evaluasi produk, yang evaluasinya hanya dilakukan pada akhir pembelajaran saja.
\end{abstract}

Kata kunci: pelatihan pelayanan publik, evaluasi pembelajaran, CIPP 


\section{PENDAHULUAN}

Undang-Undang Nomor 5 Tahun 2014 tentang Manajemen Aparatur Sipil Negara (ASN) menyebutkan bahwa pegawai ASN bertugas memberikan pelayanan publik yang profesional dan berkualitas. Pelayanan publik adalah rangkaian kegiatan dalam rangka pemenuhan kebutuhan pelayanan sesuai dengan peraturan perundangundangan bagi setiap warga negara dan penduduk atas barang, jasa dan/atau pelayanan administratif yang disediakan oleh penyelenggara pelayanan publik (Undang-Undang Nomor 25 Tentang Pelayanan Publik, 2009).

Penyelenggaraan pelayanan publik harus diselenggarakan dengan professional dan berkualitas sebagai upaya untuk mewujudkan penyelenggaraan pemerintahan secara benar (good-governance) dan bersih (clean-government), untuk mewujudkan hal tersebut diperlukan unsur-unsur mendasar antara lain adalah unsur profesionalisme dari pelaku dan penyelenggara pemerintahan dan pelayanan publik. Profesionalitas seorang aparatur negara dapat dilihat dari aspek pengetahuan, keahlian, pengalaman, etika dan kemampuan kerja (Hermawan, 2015).

Berdasarkan Peraturan Badan Kepegawaian Negara Nomor 8 Tahun 2019 tentang Pedoman Tata Cara dan Pelaksanaan Pengukuran Indeks Profesionalitas Aparatur Sipil Negara, menyebutkan bahwa profesionalitas adalah kualitas sikap anggota suatu profesi serta derajat pengetahuan dan keahlian yang dimiliki untuk dapat melakukan tugas-pekerjaan sesuai standar dan persyaratan yang ditentukan. Kualifikasi, kompetensi, kinerja dan disiplin dapat terangkum dalam suatu bentuk pelayanan publik yang dapat langsung dinilai oleh masyarakat melalui praktik penyelenggaraan pelayanan publik.

Kondisi saat ini menunjukan bahwa sumber daya manusia ASN terkait dengan profesionalisme dan kompetensi dalam penyelenggaran pelayanan publik masih jauh dari apa yang diharapkan oleh masyarakat. Data yang dikeluarkan oleh BKN mengenai nilai Indeks Profesionalisme (IP) ASN provinsi tahun 2019 secara keseluruhan berada dalam kategori "rendah". Kalaupun ada di level "sedang", hanya 3 provinsi yakni DKI Jakarta, Jawa Barat dan Sumatera Barat. 31 provinsi lainnya bercokol pada kelompok rendah/sangat rendah. Dalam dokumen yang dirilis BKN melalui Direktorat Jabatan ASN tersebut juga, dinyatakan bahwa dimensi kualifikasi dan dimensi kompetensi pegawai ASN hanya ada 6 provinsi yang teridentifikasi memiliki kualifikasi dan kompetensi sudah diatas 60\% yaitu DKI Jakarta, Kaltara, DI Yogyakarta, Jawa Timur, Jawa Barat dan Sumatera Barat. Provinsi lainnya bercokol pada kelompok rendah/sangat rendah termasuk Provinsi Banten dan Provinsi Kalimantan Barat yang merupakan 
wilayah kerja DKI Jakarta. https://bkd.sultengprov.go.id/index.p $\mathrm{hp} / 2020 / 10 / 21 /$ bkn-rilis-indeks.

Hasil survei mengenai indeks persepsi masyarakat terhadap profesionalitas ASN yang dirilis oleh Center for Study of Governance and Administrative Reform Universitas Indonesia (CSGAR UI) memperlihatkan nilai indeks persepsi masyarakat mengenai profesionalitas ASN tahun 2019 berada pada kategori profesionalitas sedang dengan nilai indeks sebesar 67,2. Hal ini mengindikasikan bahwa masyarakat memiliki persepsi yang belum baik atas dimensi-dimensi yang ada dalam penilaian profesionalitas, namun responden juga menginginkan adanya peningkatan profesionalitas ASN, terutama dalam hal keterampilan serta sikap ASN (CSGAR, 2019).

Gambaran kondisi dari aparatur tersebut mendorong BDK Jakarta sebagai unit pelaksana tugas pembinaan pegawai untuk melakukan upaya perubahan peningkatan kompetensi dan keterampilan pada sumber daya manusia ASN pada Kementerian Agama yang berada di wilayah kerjanya melalui berbagai pelatihan salah satunya adalah Pelatihan Teknis Pelayanan Publik.

Peningkatan kompetensi dalam pelayanan publik adalah salah satu titik penting dari keseluruhan reformasi administrasi. Aspek yang paling mendasar dari reformasi pelayanan publik adalah reformasi pola pikir yaitu pergeseran pola penyelenggaraan pelayanan publik dari berorientasi pada pemerintah menjadi berorientasi pada masyarakat. Dengan memperhatikan hal tersebut maka untuk mengakomodir kebutuhan aparatur dalam meningkatkan profesionalitas dan kualitas pelayanan publik di lingkungan Kementerian Agama BDK Jakarta melakukan pelatihan teknis pelayanan publik.

Pelatihan teknis pelayanan publik merupakan proses pendidikan yang berlangsung secara singkat bagi penyelenggara pelayanan publik yang bertujuan untuk menguasai berbagai keterampilan dan teknik pelaksanaan kerja tertentu, terinci dan rutin bagi penyelenggara pelayanan publik, guna memperoleh dan mengembangkan keterampilan sehingga mampu memberikan pelayanan yang berkualitas dan profesional sesuai dengan job description di tempat tugas masing-masing (Keputusan Kepala Badan Litbang dan Diklat Kementerian Agama Nomor 14 Tahun 2021 Tentang Kurikulum Pelatihan Tenaga Administrasi Pada Kementerian Agama, 2020).

Setelah mengikuti pelatihan ini diharapkan peserta memiliki pengetahuan dan keterampilan serta peningkatan motivasi kerja pegawai dalam melaksanakan tugas dan fungsi sebagai ASN pelayan masyarakat yang profesional pada tupoksi di tempat tugas masing-masing (PMA Nomor 19, 2020). 
Sebuah program pelatihan umumnya disusun berdasarkan kebutuhan akan peningkatan kompetensi yang diharapkan akan dipenuhi atau pemenuhan gap kinerja antar pegawai. Program pelatihan tentunya disusun sesuai dengan apa yang di butuhkan sehingga program pelatihan yang nantinya diselenggarakan berjalan baik dan lancar. Penyelenggaraan program pelatihan yang baik dan lancar belum tentu optimal, karena bisa jadi masih banyak persoalan yang terjadi. Untuk mengukur tingkat keberhasilan program pelatihan apakah program pelatihan sudah sesuai degan tujuan yang telah ditetapkan perlu dilakukan kegiatan evaluasi. Evaluasi program dapat didefinisikan sebagai kegiatan sistematis untuk mengumpulkan, mengolah, menganalisis dan menyajikan atau menyediakan data sebagai masukan bagi pengambilan keputusan tentang program tersebut (Sudjana, 2006).

Sebagai rangkaian sebuah manajemen pelatihan. Evaluasi program pelatihan merupakan evaluasi yang bersifat holistik, yang dipergunakan untuk menilai efektivitas dan efisiensi suatu program pelatihan. Proses evaluasi program pelatihan tidak dapat berdiri sendiri karena proses evaluasi program pelatihan merupakan sebuah proses yang berkesinambungan mulai dari perencanaan pelatihan (penyusunan kurikulum), persiapan pelatihan - menetapkan peserta, jadwal fasilitas atau tutor (widyaiswara), serta alat bantu pembelajaran lainnya, pada saat pelaksanaan dan penyelenggaraan pelatihan, sampai kepada kegiatan evaluasi pelatihan itu sendiri (Widoyoko, 2010).

Pelaksanaan evaluasi program pelatihan juga merupakan suatu proses yang bertahap dengan berbagai langkah yang perlu dilakukan untuk mencapai tujuan evaluasi. Dengan demikian evaluasi program pelatihan dilaksanakan tidak hanya untuk mengetahui efektivitas dan efisiensi penyelenggaraan pelatihan namun juga digunakan untuk memperoleh informasi terkait dengan kekurangan yang ada sehingga nantinya program pelatihan dapat diperbaiki dan diberikan keputusan apakah dapat dilanjutkan atau tidak. Evaluasi program pelatihan juga dapat digunakan untuk mengetahui dampak dari program pelatihan terhadap peningkatan kinerja seorang pegawai. https://hspacademy.com/tag/training -evaluasi-program-pelatihan

Unsur yang amat penting dalam evaluasi program adalah tujuan. Tujuan evaluasi berfungsi sebagai pengarah kegiatan evaluasi program dan sebagai acuan untuk mengetahui efisiensi dan efektivitas kegiatan evaluasi program. Tujuan dari evaluasi program adalah untuk mengumpulkan informasi guna menentukan nilai dan manfaat objek evaluasi, mengontrol, memperbaiki, serta mengambil keputusan mengenai objek tersebut (Wirawan, 2011). 
Dalam mengevaluasi program banyak model yang bisa digunakan, meskipun antara satu dengan lainnya berbeda, namun mempunyai tujuan yang sama yaitu melakukan kegiatan pengumpulan data atau informasi yang berkenaan dengan objek yang dievaluasi, yang tujuannya menyediakan bahan bagi pengambil keputusan dalam menentukan tindak lanjut suatu program. Salah satunya adalah model CIPP yang dikembangkan dan dikenalkan pertama kali oleh Stufflebeam pada tahun 1970 di Ohio State University. CIPP merupakan singkatan dari, context evaluation: evaluasi terhadap konteks, input evaluation: evaluasi terhadap masukan, process evaluation: evaluasi terhadap proses dan product evaluation: evaluasi terhadap hasil. (Muhaimin, 2015) Stufflebeam menawarkan konsep evaluasi CIPP dengan pandangan bahwa tujuan penting evaluasi adalah bukan membuktikan, tetapi untuk memperbaiki (Mahmudi, 2011).

CIPP adalah model evaluasi yang memandang program yang dievaluasi sebagai sebuah sistem. Melalui kegiatan evaluasi ini diharapkan dapat dirumuskan strategi untuk memperbaiki program ke depan sehingga sebuah program pelatihan dapat berjalan secara baik dari sebelumnya (Arikunto \& Jabar). Model evaluasi CIPP membagi empat jenis kegiatan yang disesuaikan dengan nama model evaluasinya, yaitu konteks, input, proses dan produk. Keempat jenis kegiatan tersebut merupakan komponen dari proses sebuah program kegiatan yang dilaksanakan oleh suatu lembaga.

Penggunaan model evaluasi CIPP dalam penelitian ini dikarenakan model ini mempunyai beberapa kelebihan yaitu dapat dilakukan ketika program belum dimulai dan selama program berlangsung model evaluasi ini juga ditujukan untuk melayani kebutuhan orang-orang yang merencanakan dan melaksanakan sebuah program dan keputusan dalam model CIPP berupa penilaian apakah kebutuhankebutuhan dan sasaran program sudah atau belum terpenuhi.

\section{METODE}

Penelitian ini merupakan studi deskriptif evaluatif dengan pendekatan kualitatif. Penelitian ini menggunakan data primer dan data sekunder. Data primer diperoleh dari sumber data di lokasi penelitian, sedangkan data sekunder diolah dari hasil dokumentasi, hasil wawancara, studi dokumentasi dan pengamatan lapangan.

Teknik pengumpulan data dilakukan dengan cara wawancara, observasi dan penelusuran dokumen serta angket (kuesioner). Wawancara dilakukan dengan warga belajar (peserta). Untuk melakukan verifikasi terhadap informasi yang didapat dari warga belajar (peserta) sebagai informan, mengumpulkan informasi dari beberapa informan lain, 
diantaranya adalah Kasie Diklat Administrasi, Panitia Penyelenggara dan tutor (widyaiswara). Observasi dilakukan untuk memperoleh data sarana prasarana dan data pelengkap terkait persiapan dan pelaksanaan pelatihan serta penelusuran dokumen yang dapat memberikan data dan informasi pendukung mengenai pelatihan teknis pelayanan publik, seperti laporan penyelengaraan, daftar peserta, daftar nama tutor (widyaiswara) dan lain-lain.

Analisis data dilakukan selama pengumpulan data berlangsung. Teknik analisis yang digunakan mencakup tiga proses yaitu reduksi data, penyajian data dan penggambaran serta pembuktian dan melakukan interpretasi terhadap data yang sudah terkumpul. Artinya data-data yang telah dikumpulkan yang terdiri dari deskripsi dan uraiannya, kemudian disusun agar dengan mudah dapat dipahami, kemudian diikuti penyusunan sajian data yang berupa cerita sistematis, selanjutnya dilakukan usaha untuk menarik kesimpulan.

\section{HASIL DAN PEMBAHASAN}

\section{Evaluasi Konteks (Context)}

Evaluasi konteks berusaha mengevaluasi status objek secara keseluruhan, mengidentifikasi kekurangan, kekuatan, mendiagnosa problem dan memberikan solusinya, menguji apakah tujuan dan prioritas disesuaikan dengan kebutuhan yang akan dilaksanakan. (Darodjat \& M,
2015) Evaluasi konteks adalah evaluasi yang melibatkan analisis dasar program itu sendiri, kebutuhan program serta hal-hal yang berkaitan dengan program tersebut (Hurmaini, 2015)

\section{Kesesuaian Program dengan kebutuhan Peserta}

Program pelatihan teknis pelayanan publik yang dilaksanakan oleh BDK Jakarta diselenggarakan berdasarkan kebutuhan warga belajar yaitu para pegawai pelaksana pelayanan publik di lingkungan kantor Kementerian Agama di wilayah kerja BDK Jakarta. Program ini dirancang sesuai dengan kebutuhan yang ada dilapangan. Hasil kuesioner yang diberikan kepada peserta pelatihan teknis pelayanan publik untuk pertanyaan apakah kurikulum dan materi pelatihan sesuai dengan harapan dan bermanfaat bagi peserta dalam melaksanakan tugasnya. 72 orang peserta $(72,67 \%)$ menjawab sangat sesuai dan 36 orang peserta $(36,33 \%)$ menjawab sesuai, sebagaimana Gambar 1.

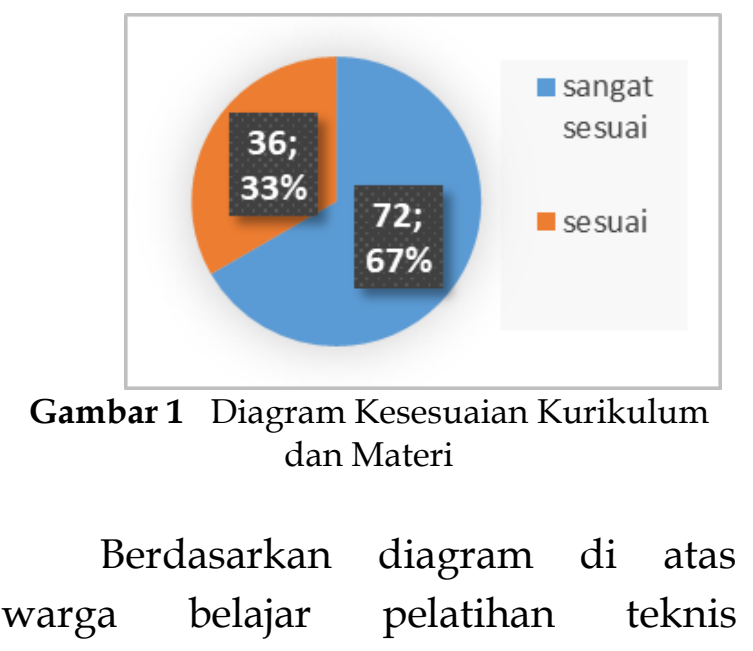


pelayanan publik sebagian besar berpendapat bahwa pelatihan teknis pelayanan publik yang diselenggarakan oleh BDK Jakarta telah sesuai dengan kebutuhan warga belajar. Hal ini diperkuat dari hasil wawancara dengan Bapak Iwan salah seorang panitia penyelenggara mengatakan bahwa "program pelatihan teknis pelayanan publik ini dilaksanakan juga berdasarkan hasil analisis kebutuhan diklat (AKD) yang dilakukan oleh BDK Jakarta terhadap beberapa satker yang menjadi wilayah kerjanya". Senada dengan yang disampaikan oleh Bapak M. Nasrul penanggung jawab pelatihan ini mengatakan bahwa: "Pelatihan teknis pelayanan publik ini dilakukan berdasarkan analisis kebutuhan diklat yang dilakukan pada Desember 2020 di dan permintaan beberapa satuan kerja yang merupakan wilayah kerja BDK Jakarta"

\section{Tujuan Pembelajaran}

Tujuan pembelajaran pada dasarnya merupakan harapan, yaitu apa yang diharapkan dari warga belajar sebagai hasil belajar.(Asra \& Sumiati, 2011) Berdasarkan Keputusan Kepala Badan Penelitian dan Pengembangan dan Pendidikan dan Pelatihan Kementerian Agama Republik Indonesia Nomor 14 Tahun 2020 tentang Kurikulum Pelatihan Tenaga Administrasi Pada Kementerian Agama dinyatakan bahwa tujuan pembelajaran pada pelatihan teknis pelayanan publik ini adalah agar peserta dapat melaksanakan tugas sebagai penyelenggara pelayan publik atau masyarakat secara professional dan berkualitas sesuai dengan job description di tempat tugas masing-masing.

\section{Evaluasi Masukan (Input)}

Orientasi utama evaluasi masukan (input) adalah menentukan cara bagaimana tujuan program dicapai. Evaluasi masukan dapat membantu mengatur keputusan, menentukan sumber-sumber yang ada, alternatif apa yang diambil, apa rencana dan strategi untuk mencapai tujuan, bagaimana prosedur kerja untuk mencapainya. Komponen evaluasi masukan meliputi sumber daya manusia, sarana dan peralatan pendukung. (Stufflebeam, D.L., Shinfield, 1985)

\section{Warga Belajar (Peserta)}

Setiap warga belajar atau peserta pelatihan mempunyai karakteristik yang meliputi atribut fisik yang berupa usia, atribut psikis yang berupa motivasi belajar dan atribut fungsional yang berupa tingkat Pendidikan. (Sudjana, 2006, p. 24) Warga belajar pada pelatihan ini adalah pegawai ASN baik fungsional maupun pelaksana yang bertugas di lingkungan Kementerian Agama pada wilayah kerja BDK Jakarta. Proses perekrutan peserta dilakukan oleh unit kerja masingmasing dengan mempertimbangkan berbagai persyaratan yang ditentukan oleh pihak penyelenggara yaitu BDK Jakarta. Adapun persyaratan untuk 
menjadi peserta pelayihan ini antara lain: ditugaskan oleh satuan kerja masing-masing, membwa persyaratan administrasi seperti pas photo, sanggup mengikuti pelatihan secara penuh dan lain sebagainya.

Proses pemberitahuan mengenai pelatihan ini dengan cara penyelenggara memberitahukan secara resmi kepada unit kerja. Sebagaimana yang disampaikan oleh salah seorang panitia Bapak Eko yang mengatakan bahwa:

$$
\text { “proses pemberatahuan }
$$
mengenai kegiatan ini dilakukan oleh panitia yang sudah dibentuk melalui SK pimpinan. Selanjutnya panitia memberitahukan secara resmi kepada kantor kementerian agama yang berada di wilayah kerja BDK Jakarta yang menjadi lokasi pelaksanaan pelatihan, selanjutnya mereka membuat surat tugas dan mengirim peserta dengan memenuhi persyaratan yang sudah ditentukan oleh penyelenggara".

\section{Berdasarkan penelusuran} dokumen terhadap pedoman penyelenggaraan pelatihan yang dikeluarkan oleh penyelenggara pelatihan teknis pelayanan publik disebutkan bahwa persyaratan untuk mengikuti pelatihan teknis pelayanan publik antara lain adalah: 1) Siap dan mampu mengikuti seluruh program pelatihan; 2) PNS atau Non PNS pelaksana fungsional atau administrasi berusia paling tinggi 4 (empat) tahun sebelum memasuki usia pensiun. 3) membawa dokumen SK terakhir, surat tugas, nomor rekening tabungan; pas photo berwarna dengan latar belakang merah (untuk laki-laki mengenakan kemeja berjas warna gelap dan berdasi dan wanitia memakai pakaian yang sopan).

Adapun jumlah warga belajar yang menjadi peserta pada pelatihan ini berjumlah 120 orang dengan rincian pada Tabel 1.

Tabel 1 Jumlah Warga Belajar Perangkatan

\begin{tabular}{ccccc}
\hline Angkatan & PNS & $\begin{array}{c}\text { Non } \\
\text { PNS }\end{array}$ & LK & PR \\
\hline 1 & 25 & 15 & 17 & 23 \\
\hline 2 & 18 & 22 & 27 & 13 \\
\hline 3 & 21 & 19 & 24 & 16 \\
\hline Jumlah & 64 & 56 & 68 & 52 \\
\hline
\end{tabular}

\section{Tutor}

Fasilitator atau tutor adalah seseorang yang melayani dan memperlancar aktivitas belajar peserta pelatihan untuk mencapai tujuan berdasarkan pengetahuan dan pengalaman. (Ikka Kartika, 2011, p. 78) Dalam pelatihan teknis pelayanan publik ini yang menjadi fasilitator atau tutor adalah Widyaiswara BDK Jakarta yang sudah mengikuti ToT atau ToF pelayanan publik. Persyaratan telah mengikuti ToT atau ToF bagi widyaiswara yang menjadi tutor dalam pelatihan ini adalah sesuatu yang sangat penting guna menjamin, mempertahankan dan meningkatkan profesionalitas yang sudah dimiliki oleh tutor, dengan meng-update 
pengetahuan dan informasi serta fleksibilitas terhadap perubahanperubahan terkait dengan substansi melalui Program ToT atau ToF akan menghasilkan widyaiswara yang berkualitas dan berkompeten untuk memberikan pembelajaran dalam pelatihan serta akan berdampak positif terhadap kepuasan peserta terhadap pembelajaran yang diberikan tutor.

Hasil evaluasi yang dilakukan penyelengara terhadap tingkat kepuasan peserta terhadap tutor dalam pelatihan dapat dilihat pada Tabel 2 .

Tabel 2 Kepuasan Peserta Terhadap Tutor Pelatihan Teknis Pelayanan Publik

\begin{tabular}{llcc}
\hline \multirow{2}{*}{ No } & \multicolumn{1}{c}{ Pernyataan } & \multicolumn{2}{c}{ Hasil } \\
& \multicolumn{1}{c}{ SM } & M \\
\hline 1 & $\begin{array}{l}\text { Pengetahuan } \\
\text { Widyaiswara } \\
\text { terhadap materi yang } \\
\text { diajarkan }\end{array}$ & 76 & 44 \\
\hline 2 & $\begin{array}{l}\text { Kemampuan dalam } \\
\text { melibatkan partisipasi } \\
\text { peserta }\end{array}$ & 84 & 36 \\
\hline 3 & $\begin{array}{l}\text { Kemampuan } \\
\text { memotivasi peserta }\end{array}$ & 85 & 35 \\
\hline 4 & $\begin{array}{l}\text { Kemampuan dalam } \\
\text { menanggapi } \\
\text { permasalahan dan } \\
\text { pertanyaan peserta }\end{array}$ & 87 & 33 \\
\hline 5 & $\begin{array}{l}\text { Kemampuan } \\
\text { Widyaiswara dalam } \\
\text { menggunakan media } \\
\text { pembelajaran }\end{array}$ & & \\
\hline
\end{tabular}

Keterangan:

SM : Sangat Memuaskan

M : Memuaskan

Berdasarkan data diatas diperoleh hasil bahwa tingkat kepuasan warga belajar terhadap pengetahuan widyaiswara, kemampuan dalam melibatkan partisipasi peserta, memotivasi peserta, menanggapi permasalahan dan pertanyaan peserta dan kepuaasan peserta terhadap kemampuan widyaiswara dalam menggunakan media pembelajaran $70 \%$ menyatakan sangat memuaskan dan $30 \%$ meyatakan memuaskan.

Dari hasil wawancara yang dilakukan kepada Bapak M. Nuh salah seorang peserta pelatihan mengatakan bahwa "Widyaiswara dalam pelatihan ini menguasai substansi materi yang diajarkan sehingga peserta mudah memahami materi." Senada dengan Ibu Nurhayati salah seorang peserta juga mengatakan bahwa "widyaiswara dalam pelatihan ini kompeten dan menguasai materi yang diberikan dalam pelatihan pelayan publik ini dan membuat peserta puas".

\section{Pendanaan}

Penyelenggaraan pelatihan teknis pelayanan publik yang dilaksanakan oleh BDK Jakarta ini dilaksanakan tanpa dipungut biaya apapun. Berdasarkan panduan penyelenggara pelatihan teknis pelayanan publik yang dikeluarkan oleh panitia penyelenggara pelatihan ini dinyatakan bahwa sumber dana pelatihan pelayanan publik adalah DIPA Balai Pelatihan Keagamaan Jakarta Nomor SP DIPA 025.11.2.425375/2021 tanggal 23 November 2020. 


\section{Sarana dan prasarana}

Secara keseluruhan sarana dan prasarana yang yang dibutuhkan dalam pelaksanaan Pelatihan Teknis Pelayanan Publik bisa dikatakan baik. Sarana dan prasarana dalam pelaksanaan pelatihan disediakan langsung oleh BDK Jakarta bekerjasama dengan panitia lokal yaitu lokasi penyelenggara PDWK yang sudah terlebih dahulu dihubungi dan diminta kesediannya menjadi panitia lokal, adapun sarana dan prasarana yang dipersiapkan adalah ruangan, infokus, pengeras suara, kursi, ac, alat tulis bagi peserta pelatihan serta modul.

Berdasarkan hasil evaluasi yang dilakukan oleh penyelenggara kepada warga belajar mengenai tingkat kepuasan peserta terhadapa sarana dan prasarana yang digunakan dalam pelatihan ini dapat dilihat pada Gambar 2.

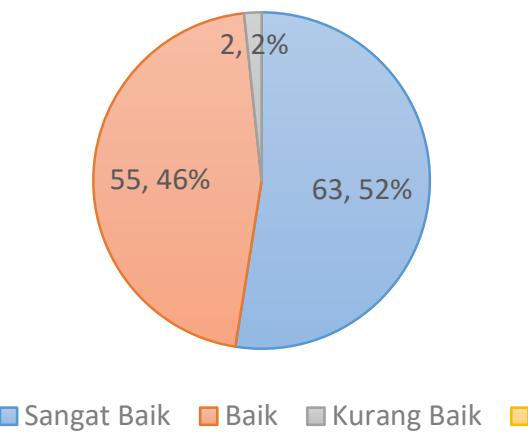

Gambar 2 Diagram Kepuasan Peserta Terhadap Sarana \& Prasarana

\section{Evaluasi Proses}

Esensi dari evaluasi proses adalah untuk mengecek pelaksanaan suatu rencana/program. Tujuannya adalah untuk memberikan feedback bagi manajemen dan staf tentang aktivitas program yang berjalan apakah sesuai dengan jadwal dan menggunakan sumber-sumber yang tersedia secara efisien, memberikan bimbingan untuk memodifikasi rencana agar sesuai dengan yang dibutuhkan, mengevaluasi secara berkala seberapa besar faktor yang terlibat dalam aktifitas program dapat menerima dan melaksanakan peran atau tugasnya. (Stufflebeam, D.L., Shinfield, 1985)

\section{Aktivitas Warga Belajar}

Warga belajar dalam program pelatihan teknis pelayanan publik ini memperoleh pembelajaran dengan cara yang sama dari masing-masing tutor. Tutor tidak membedakan antar warga belajar yang satu dengan warga belajar yang lainnya dengan harapan warga belajar dapat melakukan aktivitas belajarnya dengan maksimal.

Berdasarkan hasil pengamatan yang dilakukan oleh penulis menunjukkan bahwa aktivitas sesama warga belajar maupun antara warga belajar dengan tutor berlangsung baik dan penuh semangat dalam mengikuti pelatihan tersebut. Hal ini sesuai dengan hasil pengamataan dari daftar hadir warga belajar dalam mengikuti pembelajaran yang ditandai dengan tidak adanya peserta yang absen dalam mengikuti pembelajaran program pelatihan teknis pelayanan publik ini.

Berdasarkan hasil wawancara yang dilakukan kepada Bapak Eko dan Ibu Edwita selaku akademis pada 
masing-masing angkatan mengatakan bahwa tingkat kehadiran warga belajar dalam mengikuti pelatihan telah mencapai hasil yang maksimal yaitu $100 \%$ dan interaksi antara sesama peserta dan antara peserta dengan tutor juga berjalan dengan baik. Bapak Asep sebagai salah seorang warga belajar juga menyatakan bahwa: "komunikasi antara peserta dengan tutor berlangsung baik hal ini dapat dilihat apabila ada yang tidak dimengerti oleh kami sebagai peserta kami tidak segansegan untuk bertanya dan berdiskusi dengan wi sebagai tutor". Ibu Fadilah sebagai salah seorang peserta dalam pelatihan ini mengatakan bahwa "kami sangat senang dengan pelatihan teknis pelayanan publik ini, karena kami mendapatkan ilmu dan skill dalam melaksanakan tugasnya, sehingga kami akan berusaha menjadi lebih kompeten dan profesional dalam memberikan pelayanan publik sesuai dengan tugas dan fungsinya di tempat tugas kami masing-masing".

Dengan demikian dapat dinyatakan bahwa mengikuti pelatihan ini banyak pengetahuan dan pengelaman yang didapatkan dari hasil diskusi dengan tutor dan sesama peserta terkait dengan penyelenggaraan pelayanan publik yang sesuai dengan ketentuan yang beraku dan harapan masyarakat pengguna layanan publik itu sendiri.

\section{Aktivitas Tutor}

Kegiatan yang tutor lakukan dalam pelaksanaan pembelajaran sangat banyak membantu proses pembelajaran Pelatihan Teknis Pelayanan Publik yang diadakan di wilayah kerja BDK Jakarta. Tutor memberikan pembelajaran berdasarkan Kurikulum dan silabus yang telah disusun oleh Lembaga Pembina yaitu Pusdiklat Tenaga Administrasi Kementerian Agama, selanjutnya tutor menysusun RBPMP dan RP yang kemudian diimplementasikan dalam pembelajaran. Dalam pelaksanaannya tutor memberikan pembelajaran pada mata pelatihan inti sebanyak 42 jam pelajaran dalam 5 kali pertemuan yang mana pertemuannya dilakukan sebanyak 5 kali dalam satu minggu.

\section{Metode}

Metode mengajar pada dasarnya adalah tindakan nyata dari guru atau merupakan praktek guru atau tutor melaksanakan pengajaran melalui cara tertentu yang dinilai lebih efektif dan efisien.(Martinis, 2005, p. 31) Dalam pelatihan ini pelaksaan pembelajaran metode yang digunakan adalah metode ceramah, diskusi dan praktik atau simulasi. Pertama-tama tutor memberikan materi dengan metode ceramah. Metode ceramah ini digunakan untuk memaparkan materimateri yang relevan dengan pembelajaran kemudian dilanjutkan dengan diskusi. Diskusi sangat diperlukan warga belajar dapat 
mengemukakan permasalahan yang mereka hadapi dan dicari jalan keluarnya bersama-sama dengan tutor sebagai orang yang ahli dalam bidangnya. Selanjutnya adalah praktik. Praktik biasanya dilakukan untuk memperagakan berbagai kegiatan dalam penyelenggaraan pelayanan publik yang seharusnya dilakukan oleh para peserta yang merupakan petugas penyelenggara pelayanan public di unit kerjanya masing-masing.

Berdasarkan hasil evaluasi mengenai tingkat kepuasan peserta terhadap metode pembelajaran yang digunakan dalam pelatihan ini dapat dilihat pada Gambar 3.

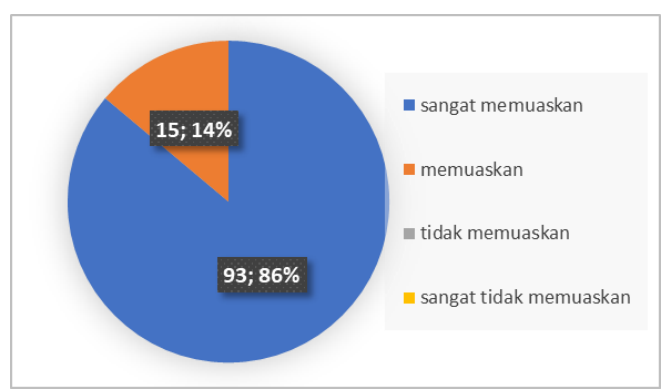

Gambar 3 Diagram Kepuasan Peserta Terhadap Metode Pembelajaran

\section{Materi pembelajaran}

Materi pembelajaran atau sering disebut mata pelatihan dalam kegiatan ini dibagi menjadi 3 kelompok yaitu kelompok dasar, kelompok inti dan kelompok penunjang. Mata pelatihan tersebut adalah pokok-pokok materi pembelajaran yang harus dipelajari warga belajar sebagai sarana pencapaian kompetensi dasar dan yang akan dinilai dengan menggunakan instrumen penilaian yang disusun berdasarkan indikator ketercapaian kompetensi. (Kurikulum Pelatihan Tenaga Administrasi Pada Kementerian Agama, 2020)

Materi pembelajaran yang diberikan kepada warga belajar disusun dalam bentuk silabus program pelatihan. Yang mana terdiri atas 54 jam pelajaran, yang dibagi ke dalam 3 kelompok mata pelatihan yaitu : 1) Kelompok dasar, 2) Kelompok inti, 3) kelompok penunjang. Rincian mata pelatihan ketiga kelompok tersebut dapat dilihat pada Tabel 3.

Tabel 3 Struktur Kurikulum Pelatihan Teknis Pelayanan Publik

\begin{tabular}{|c|c|c|c|}
\hline \multirow[t]{2}{*}{ No } & \multirow[t]{2}{*}{ Mata Pelatihan } & \multicolumn{2}{|c|}{$\begin{array}{l}\text { Jumlah } \\
\text { JP }\end{array}$} \\
\hline & & $\mathbf{T}$ & $\mathbf{P}$ \\
\hline \multicolumn{4}{|c|}{ Kelompok Dasar } \\
\hline & $\begin{array}{l}\text { Pembangunan Bidang } \\
\text { Agama }\end{array}$ & 3 & - \\
\hline 2. & $\begin{array}{l}\text { Pengembangan Sumber Daya } \\
\text { Manusia }\end{array}$ & 3 & - \\
\hline 3. & $\begin{array}{l}\text { Peningkatan dan Penjaminan } \\
\text { Mutu Diklat }\end{array}$ & 3 & - \\
\hline & Jumlah & 9 & - \\
\hline \multicolumn{4}{|c|}{ Kelompok Inti } \\
\hline 1. & $\begin{array}{l}\text { Konsep dan Kebijakan } \\
\text { Pelayanan Publik }\end{array}$ & 3 & \\
\hline 2. & Desain Pelayanan Publik & 3 & 7 \\
\hline 3. & $\begin{array}{l}\text { Implementasi \& Pengawasan } \\
\text { Pelayanan Publik }\end{array}$ & 3 & 7 \\
\hline 4. & $\begin{array}{l}\text { Pengelolaan Pengaduan } \\
\text { Masyarakat }\end{array}$ & 3 & 3 \\
\hline 5. & $\begin{array}{l}\text { Indeks Kepuasan Masyarakat } \\
\text { Jumlah }\end{array}$ & $\begin{array}{c}3 \\
15\end{array}$ & $\begin{array}{c}5 \\
22 \\
\end{array}$ \\
\hline \multicolumn{4}{|c|}{ Kelompok Penunjang } \\
\hline & Overview & 2 & - \\
\hline 2. & Pretest $\mathcal{E}$ Postest & & 2 \\
\hline 3. & Building Learning Comitment & - & 3 \\
\hline & Evaluasi Program & 1 & - \\
\hline & Jumlah & 4 & 5 \\
\hline & Jumlah Total & 27 & 27 \\
\hline & otal Jam Pembelaiaran ( & P) & \\
\hline
\end{tabular}




\section{Partisipasi Program Pelatihan}

Partisipasi merupakan hal yang sangat penting dalam sebuah pelatihan. Karena pelatihan bisa dikatakan baik apabila partisipasi dari warga belajarnya bagus. Partisipasi warga belajar dapat dilihat dari keaktifan warga belajar di dalam kelas dan kehadiran mereka. Dalam pelatihan ini berdasarkan pengamatan yang dilakukan oleh peneliti sebanyak 6 hari pertemuan tingkat kehadiran peserta sangat bagus. Hal ini diperkuat dengan daftar hadir atau presensi peserta selamam pembelajaran berlangsung tingkat kehadiran $100 \%$. Dalam proses pembelajaran para warga belajar selalu antusias dalam menanyakan hal-hal yang berhubungan dengan materi yang disampaikan, serta berpartisipasi dalam diskusi dan penugasan yang diberikan baik penugasan yang sifatnya individu maupun kelompok.

\section{Evaluasi Produk}

Tujuan dari Product Evaluation (evaluasi hasil) adalah untuk mengukur, menafsirkan dan menetapkan pencapaian hasil dari suatu program, memastikan seberapa besar program telah memenuhi kebutuhan suatu kelompok program yang dilayani. (Stufflebeam, D.L., Shinfield, 1985, p. 76). Evaluasi produk merupakan penilaian yang dilakukan untuk mengukur keberhasilan dalam pencapaian tujuan yang telah ditetapkan. Data yang dihasilkan akan sangat menentukan apakah program diteruskan,

dimodifikasi

atau dihentikan.

\section{Ketercapaian Tujuan Program}

Evaluasi merupakan salah satu kegiatan yang penting dalam pelaksaan sebuah program untuk melihat keberhasilan sebuah program. Evaluasi program pelatihan yang dimaksud adalah proses identifikasi, klarifikasi dan penerapan kriteria untuk menentukan nilai suatu objek evaluasi (nilai atau manfaat) berkaitan dengan penguasaan materi kemampuan peserta dalam menguasai hasil pembelajarn dan indikator hasil belajar program pelatihan. (Fitzpatrick \& Sanders, 2013)

Tujuan utama dari pelatihan teknis pelayanan publik ini adalah warga belajar memiliki pengetahuan dan keterampilan serta peningkatan motivasi kinerja pegawai dalam melaksanakan tugas dan fungsi sebagai ASN pelayan masyarakat yang professional dan berkualitas sesuai dengan tupoksi di tempat tugas masingmasing dengan indicator keberhasilan adalah : 1) warga belajar mampu memahami konsep dan kebijakan pelayan publik; 2) mampu mendesain dan membuat standar pelayanan publik sesuai dengan tugas masing-masing; 3 ) mampu membuat standar pelayanan publik, mengelola pengaduan masyarakat terhadap pelayanan publik serta 4) mampu menyusun instrument dan melakukan pengukuran survei indek kepuasan masyarakat sesuai dengan aturan yang berlaku. 
(Kurikulum

Pelatihan

Tenaga

Administrasi

\section{Pada}

Kementerian

Agama, 2020)

Dari hasil evaluasi yang dilakukan

oleh tutor terhadap penguasaan substansi materi warga belajar dengan memberikan tugas yang diberikan kepada warga belajar baik tugas individu maupun tugas kelompok didapatkan hasil pada Tabel 4.

Tabel 4 Evaluasi Peserta

\begin{tabular}{|c|l|l|c|}
\hline No & \multicolumn{1}{|c|}{ Skor } & \multicolumn{1}{c|}{ Kualifikasi } & \% \\
\hline 1 & $90,01-100$ & Sangat memuaskan & 22,5 \\
\hline 2 & $80,01-90,0$ & Memuaskan & 52,5 \\
\hline 3 & $70,01-$ & Baik & 25 \\
& 80,00 & & \\
\hline 4 & $60,01-$ & Kurang baik & 0 \\
& 70,00 & & \\
\hline 5 & $\leq 60$ & Tidak memenuhi & 0 \\
\hline
\end{tabular}

Berdasarkan data di atas tujuan program pelatihan teknis pelayanan publik dilihat dari hasil evaluasi yang dilakukan tutor terhadap tugas yang diberikan baik tugas individu maupun tugas kelompok diperoleh hasil 27 warga belajar (22,5\%) kualifikasi sangat memuaskan, 63 peserta $(52,5 \%)$ warga belajar dengan kualifikasi memuaskan dan 30 warga belajar (25\%) memperoleh kualifikasi baik.

\section{Evaluasi Penyelenggaraan}

Dalam kegiatan Pelatihan Teknis Pelayanan Publik ini kegiatan evaluasi dilakukan pada akhir kegiatan pelatihan. Bentuk evaluasi yang dilaksanakan berupa angket tentang pendapat para warga belajar tentang program yang telah dilaksanakan yang diberikan oleh panitia penyelenggara
BDK Jakarta. Evaluasi yang diberikan dirasakan baik karena harapan dari kegiatan pelatihan ini adalah peserta dapat lebih memahami dan menerapkan materi yang telah diberikan dalam pelaksanaan tugas dan fungsinya sebagai penyelenggara pelayanan publik di tempat kerja masing-masing.

$$
\text { Adapun evaluasi dari }
$$
penyelenggara dalam bentuk laporan yang akan dilaporkan pada pihak manajemen dan atau pimpinan BDK Jakarta dilaporkan dalam bentuk laporan penyelenggaraan pelatihan teknis pelayanan publik.

\section{KESIMPULAN}

Pembelajaran dalam program Pelatihan Teknis Pelayanan Publik yang dilaksanakan oleh BDK Jakarta melalui pelekasanaan pelatihan di wilayah kerja (PDWK) secara keseluruhan sudah bisa dikatan baik berdasarkan evalusi yang dilakukan dengan menggunakan pendekatan model CIPP (Context, Input, Process, Product). Pada evaluasi Context pelatihan yang diselenggarakan telah berdasarkan kebutuhan warga belajarmya dan tujuan pelatihan sudah tercapai.

Pada evaluasi Input perekrutan peserta juga memiliki persyaratan tertentu yang harus dipenuhi namun tidak memberatkan peserta. Peserta pelatihan merupakan pegawai di lingkungan Kementerian Agama dan ditugaskan oleh satkernya masingmasing untuk mengikuti pelatihan. 
Widyaiswara sebagai tutor adalah seorang ahli dalam bidang substansi mata pelatihan ,menguasai Teknik dan metode pembelajaran orang dewasa serta sudah mengikuti TOT/ TOF yang dipersyaratkan. Pendanaan dalam pelatihan ini telah di danai sepenuhnya oleh DIPA BDK Jakarta.

Adapun sarana dan parasarana yang digunakan sudah baik. Evaluasi Process, pembelajaran dalam Pelatihan Teknis Pelayanan Publik ini dilakukan selama 54 jam pelajaran dan berlangsung selama 5 hari kerja. Dalam proses pelaksanaan tanggapan peserta sangat baik. Komunikasi antara warga belajar dan tutor juga sangat baik. Metode yang digunakan dalam pembelajaran ini adalah ceramah, tanya jawab, diskusi dan praktik.

Terakhir Evaluasi Product. Pembelajaran yang dilaksanakan telah sesuai dengan tujuan pembelajaran dan kompetensi yang diharapkan, hasil belajar dan indikator hasil belajar yang terdapat dalam setiap mata pelatihan. namun dalam evaluasi masih kurang karena proses evaluasi yang dilaksanakan dilakukan oleh penyelenggara pada akhir pembelajaran saja dan itu hanya berupa angket tentang tanggapan peserta terhadap pelatihan yang dilaksankan. Adapun evaluasi program yang dilakukan hanya dalam bentuk pelaporan yang dibuat oleh pennyelenggara dan dilaporkan kepada pimpinan BDK Jakarta.

\section{DAFTAR PUSTAKA}

PMA Nomor 19, Pub. L. No. 19 Tahun 2020 (2020).

Arikunto, S., \& Jabar, C. S. (2010). Evaluasi Program Pendidikan: Pedoman teoritis praktis bagi mahasiswa dan praktisi pendidikan. Bumi Aksara.

Asra, \& Sumiati. (2011). Metode Pembelajaran. CV Wacana Prima.

Keputusan Kepala Badan Litbang dan Diklat Kementerian Agama Nomor 14 Tahun 2021 tentang Kurikulum Pelatihan Tenaga Administrasi Pada Kementerian Agama, Pub. L. No. 14, 102 (2020).

CSGAR, T. P. U.-. (2019). IPM Tentang Profesionalitas dan Rebranding ASN Tahun 2019.

Darodjat, D., \& M, W. (2015). Model Evaluasi Program. Islamadina, Volume XIV(1), 1-28. 
Fitzpatrick, J. L., \& Sanders, J. R. (2013). تقويم البرنامج :طرق بديلة و إرشادات عملية = Program evaluation Alternative Approaches and Practical Guidelines. In

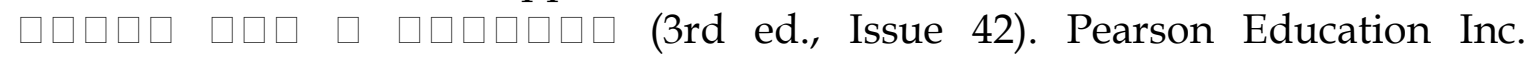
https://doi.org/10.12816/0002619

Hermawan, A. (2015). Profesionalisme Pegawai Negeri Sipil Kecamatan Landasan Ulin Kota Banjar Baru. REFORMASI, 5.

Hurmaini, M. (2015). Evaluation and Social Internship Program of IAIN Sultan Thaha Saifuddin Jambi Students: Using Context, Input, Process and Product Model (CIPP Model). Al-Ta Lim Journal, 22(1), 23-32. https://doi.org/10.15548/jt.v22i1.114

Ikka Kartika, A. F. (2011). Mengelola Pelatihan Partisipatif. Alfabeta.

Mahmudi, I. (2011). CIPP. Suatu Model Evaluasi Program Pendidikan". At, 6(1), 23.

Martinis, Y. (2005). Strategi pembelajaran Berbasis Kompetensi (54th ed.). Gaung Persada Press.

Muhaimin, M. (2015). Model Evaluasi CIPP (Context, Input, Process, Product). Kompas, 2.

Kurikulum Pelatihan Tenaga Administrasi Pada Kementerian Agama, Pub. L. No. 14, 70 (2020).

Stufflebeam, D.L., Shinfield, A. . (1985). Systematic Evaluation A Self-Instructional Guide to Theory and Practice (1st ed.). KluwerNijhof Publishing.

Sudjana, D. (2006). Evaluasi Program Pendidikan Luar Sekolah. PT. Remaja Rosda Karya. Widoyoko, E. (2010). Evaluasi Program Pembelajaran. Pustaka Pelajar.

Wirawan. (2011). Evaluasi : Teori, Model, Standar, Aplikasi dan Profesi. Rajawali Pers. 